\section{PERICNEMIS MELANSONI SP. NOV., A NEW DAMSELFLY (ODONATA: COENAGRIONIDAE) FROM COMPOSTELA VALLEY PROVINCE, MINDANAO ISLAND, PHILIPPINES}

\author{
Reagan Joseph T. Villanueva ${ }^{1}$, Milton Norman D. Medina ${ }^{2} \&$ \\ Kim M. Jumawan ${ }^{3}$
}

${ }^{1}$ D3C Gahol Apartment, Lopez Jaena St., Davao City, 8000 Philippines, 2,3 Research and Development Center, Assumption College of Nabunturan, Nabunturan, Compostela Valley Province, 8800 Philippines

Email: ${ }^{1}$ rjtvillanueva@gmail.com, ${ }^{2}$ milton_sept19@yahoo.com (corresponding author), ${ }^{3}$ kim_xv3@yahoo.com

Villanueva (2012) reviewed the Philippine members of the genus Amphicnemis. All species were transferred to three newly established genera, or moved into the genus Pericnemis. In the present sense, five named species are currently recognized as members of the genus Pericnemis in the Philippine archipelago.

The island of Mindanao has one known species of Pericnemis, Pericnemis lestoides (Brauer, 1868). In addition, nearly a dozen species are still to be described from the island. During a short biodiversity survey in Cabalian Creek, Nabunturan, Compostela Valley Province conducted by the second and third authors, specimens of Pericnemis were collected. Voucher specimens were given to the first author who confirmed they represented a species new to science. Due to the urgency of establishing the known habitat of the present species as a protected area, it is described here in advance of a complete treatment of the Philippine Pericnemis.

\section{Materials and Methods}

All material was collected by the second and third authors. Measurements were made using calipers and on the left side of the specimen. Terminology generally follows Westfall \& May (1996).

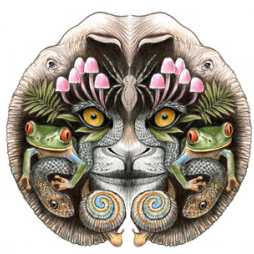

ISSN

Online 0974-7907 Print 0974-7893

\section{OPEN ACCESS} The holotype and paratypes are all deposited in Father Melanson's Museum of Natural History, Assumption College of Nabunturan, Nabunturan, Compostela Valley province, Mindanao Island, Philippines (ACN).

\section{Pericnemis melansoni sp. nov.}

(Figs. 1-6, Image 1)

urn:Isid:zoobank.org:act:7F569089-7650-4E1F-8BFE-D42D69D62030

\section{Material examined}

Holotype: Male, ACN-2012-hol-1, 22.xi.2012, Cabalian Creek, Nabunturan, Compostela Valley Province, Mindanao Island, Philippines, K. Jumawan leg.

Paratypes: 6 males, 1 female, same data as holotype, ACN-2012-Odo-Coe-X001-6m/1f.

\section{Diagnosis}

This species is closest to Pericnemis lestoides among its known congeners in the Philippines. The male differs from that species in having a simple posterior lobe of the pronotum without a pointed middle portion, and in having the lower branches of the cerci longer than the upper branches; in $P$. lestoides both branches of the cerci are of similar length. The posterior pronotal lobe of the

DOI: http://dx.doi.org/10.11609/JoTT.o3472.4110-2 | ZooBank: urn:Isid:zoobank.org:pub:F97B179C-C45D-4DFD-9A10-403F5391581F

Copyright: @ Villanueva et al. 2013. Creative Commons Attribution 3.0 Unported License. JoTT allows unrestricted use of this article in any medium, reproduction and distribution by providing adequate credit to the authors and the source of publication.

Funding: Research and Development Center, Assumption College of Nabunturan, Compostela Valley Philippines

Competing Interest: The paper is a product of a joint effort by the authors and the R\&D of Assumption College of Nabunturan - no other funding agency/ies. Hence the copyright will be between JoTT, the authors, and R\&D office of Assumption College of Nabunturan.

Acknowledgements: The authors are grateful for the funding support provided by the Assumption College of Nabunturan Administration headed by Sr. Myrna Taganas, FMA, school president and Delfin Enargan, M.A., chairman of the Research Committee and board members. We are indebted to Dr. Albert Orr who made constructive comments and especially for executing Figures 1-2 and 5 and for arranging the plate. We are thankful to the Barangay Council and the people of San Vicente, and Barangay Council of Poblacion Nabunturan. Special thanks are due to Mr. Dodong Daputan for the assistance during several expeditions in Barangay San Vicente; to Michelle Deguilmo, Raffy Paig, Shaolu Edig, and Paolo Uri for field assistance and to Nannel Aranton for facilitating the transportation and securing the needed permits. 

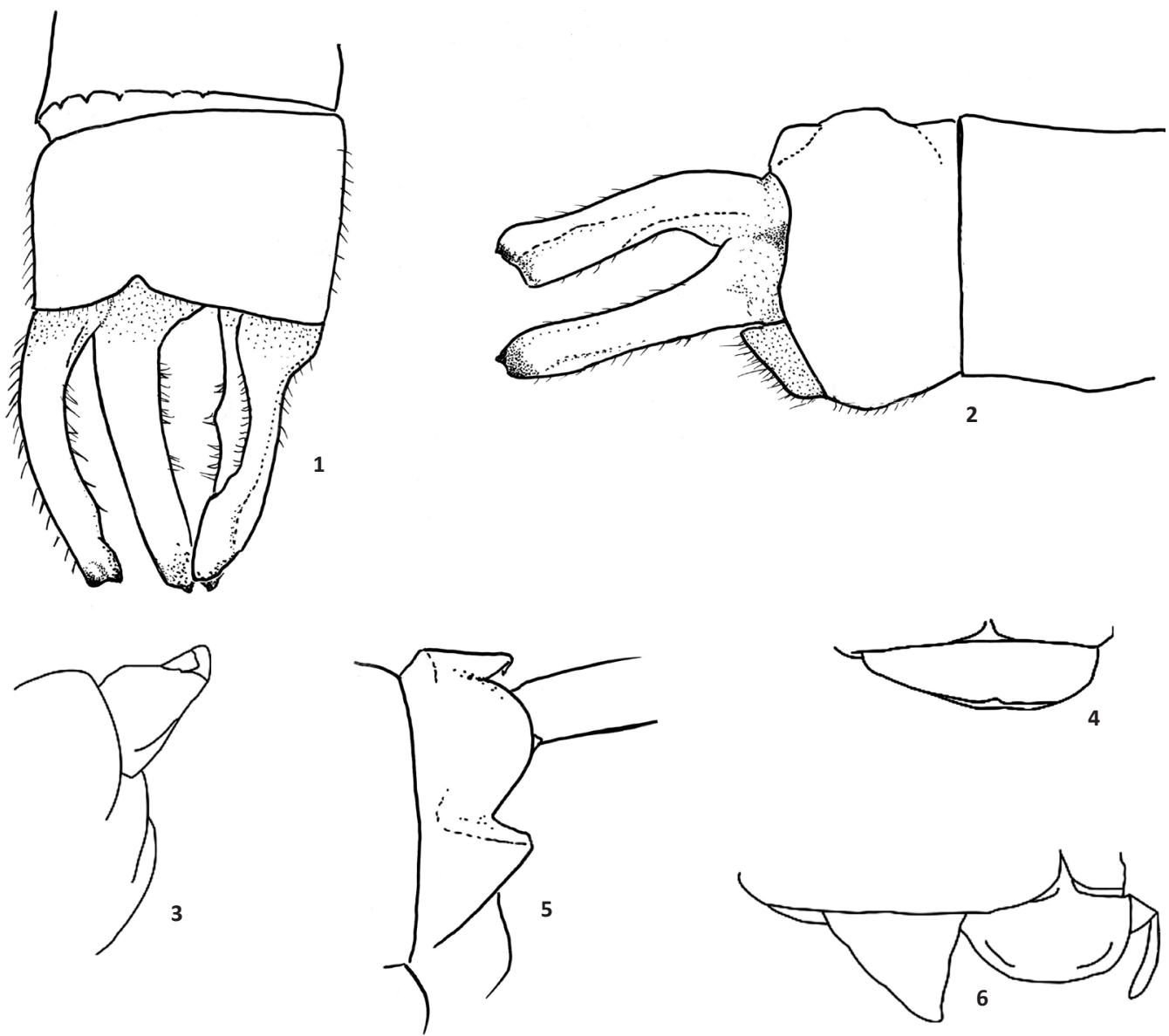

Figures 1-5. Pericnemis melansoni sp. nov.

1 - Dorsal view (slightly oblique) male superior appendages, left to right - upper branch left cercus, lower branch left cercus, lower branch right cercus (obscured) upper branch right cercus (paraprocts not visible); 2 - Lateral view of male anal appendages, showing bifid cercus and very short paraproct; 3 - Lateral view of male prothorax, posterior lobe; 4 - Dorsal view of male prothorax, posterior lobe; 5 - dorso-lateral view of female prothorax, posterior lobe; 6 - Oblique view of female prothorax, posterior lobe.

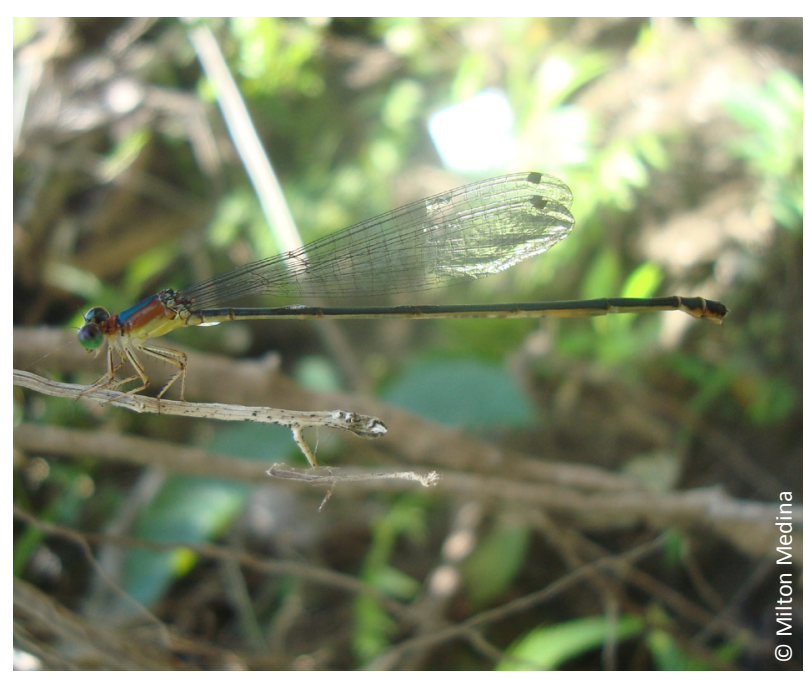

Image 1. Pericnemis melansoni sp. nov. female female of $P$. melansoni is divided into distinct middle and lateral parts.

\section{Etymology}

A noun in genitive case, after Fr. Louis Joseph Arthur Melanson (1879-1941) who founded the Les Filles 'de Marie-de-L' Assomption or the FMA congregation which runs the Assumption College of Nabunturan.

\section{Description of male}

Labium and mandibles pale, a little darker on the apices of mandibles. Remainder of head black except for pale streaks as follows; around outer margin of the labrum; across anteclypeus; transverse streak across frons a little narrowed in the midline, around borders of genae and along anterior portion of scape and pedicle.

Thorax: Prothorax metallic green. Anterior lobe short and erect. Median lobe broad and dome shaped 
with broad shallow groove running across the lateral aspect. Posterior lobe (Figs. 3-4) short and simple, its free margin rounded with unspecialized lateral corners.

Synthorax metallic green and pale laterally. Mesepisternum entirely metallic green. Mesinfraepisternum mostly metallic green. Mesepimeron metallic green except for pale posterior margin. Metepisternum pale except for metallic green patch adjacent to wing base. Metepimeron pale. Legs pale except for black spines, black streaks on extensor surface of femur, around joint of femur and tibia and on extensor surface of tibia.

Wings hyaline with black veins. Venation as for the genus, with 14 and 12 postnodals (Px) in fore wing and hind wing, respectively. R4 at subnodus. R3 situated just off subnodus, IR3 at Px8 and Px6 in forewing and hind wing, respectively. Pterostigma brown with pale margins, squarish with costal side a little shorter than subcostal side.

Abdomen brownish-black, pale ventrally. S1-2 shiny black dorsum, pale laterally. S3-6 brownish, a little darker on dorsum. S7-10 black except for pale ventro-lateral aspect of S10. Cerci bifid, (Figs. 1-2) pale except for blackened apices and brownish bases. Upper branch of cercus with basal $1 / 8^{\text {th }}$ broader than remainder in lateral view, ending in a blunt inwardly directed tooth. Lower branch of cercus clearly longer than upper branch; lower branches closely approximated apically. Paraprocts very short, broad and blunt, light brown.

Measurements [millimeters]. Hind wing: 27; abdomen + cerci: 48

\section{Female}

Similar to male except for broad brownish streak on the outer margin of labrum and whitish streak along eye margins. Prothorax brown, blackish streaks on median pronotal lobe. Posterior pronotal lobe (Figs. 5-6) sub-rectangular with middle part clearly separated from triangular lateral part. Synthorax tri-colored, mesepisternum dark metallic green, mesepimeron and posterior margin of mesepisternum orange, except for black streak on mesepimeron. Remainder of synthorax yellowish. Abdomen with S3-S6 black.

Measurements [in mm]. Hind wing: 29; abdomen: 43.

Variation: No notable variation evident except for the size of male paratypes which range from hind wing (mm): 24-28 and abdomen: 40-48.

\section{Discussion}

This species differs from most other Philippine Pericnemis, as yet undescribed by having a slender tubercle on the first segment of its genital ligula. This character is shared only with $P$. lestoides (see Villanueva 2012).

Pericnemis melansoni sp. nov. is the second described species of Pericnemis on the island of Mindanao. It is distinguished from its close relative $P$. lestoides (also found in Mindanao) in lacking an elongate posterior lobe of prothorax. In the present species, the lower branches of the cerci are longer than the upper branches whereas in $P$. lestoides the branches are of equal length. Lieftinck (1957) illustrated the female of $P$. lestoides which differs from the female of the present species by having more distinct middle and lateral parts on the posterior lobe of the prothorax.

\section{REFERENCES}

Lieftinck, M.A. (1957). On some old types of coenagrionine Odonata described from the Philippine Islands, with notes on allied species. Zoologische Mededelingen 35: 161-175.

Villanueva, R.J.T. (2012). Review of the Philippine taxa formerly assigned to the genus Amphicnemis Selys. Part I: Overview and descriptions of three new genera (Odonata: Coenagrionidae). Zoologische Mededelingen 86(8): 579-604.

Westfall, M.J. \& M.L. May (1996). Damselflies of North America. Scientific Publishers, Gainesville, x+649pp. 